\title{
Effects of ecto-5'-nucleotidase on human breast cancer cell growth in vitro and in vivo
}

\author{
XUERUI ZHOU ${ }^{1}$, XIULING ZHI ${ }^{2}$, PING ZHOU ${ }^{2}$, SIFENG CHEN ${ }^{2}$, FENGDI ZHAO ${ }^{2}$, \\ ZHIMIN $\mathrm{SHAO}^{3}$, ZHOULUO OU ${ }^{3}$ and LIANHUA YIN ${ }^{2}$ \\ ${ }^{1}$ Department of Biology, Huaiyin Teachers College, Huaian, 223001 Jiangsu; ${ }^{2}$ Department of Physiology \\ and Pathophysiology, Shanghai Medical College, ${ }^{3}$ Department of Breast Surgery, \\ Cancer Hospital, Fudan University, Shanghai 200032, P.R. China
}

Received December 30, 2006; Accepted February 20, 2007

\begin{abstract}
Ecto-5'-nucleotidase (CD73) is an essential enzyme that generates adenosine, an essential molecule for cell growth. CD73 increases significantly in many breast cancers. In this study, $\alpha, \beta$-methylene adenosine-5'-diphosphate (APCP), a specific CD73 inhibitor was used to block the hydrolase's activity. Effects of CD73 were examined on human breast cancer cells MDA-MB-231 in culture for proliferation, cell cycle progression, and apoptosis before and after APCP treatment. The in vivo effect of CD73 was examined on MDAMB-231 tumor xenograft growth in nude mice. Cell growth curve, cell cycle and apoptosis were observed with MTT assays and flow cytometry, respectively. Microvessel density (MVD) and lymph vessel density (LVD) of implanted tumor tissues was analyzed by immunohistochemistry for CD31 and VEGFR-3 staining respectively. Our results showed that APCP inhibited MDA-MB-231 viability in a dose-dependent manner. APCP $(12 \mu \mathrm{M})$ increased the percentage of $\mathrm{G}_{0} / \mathrm{G}_{1}$ phase cells from 49.75 to $59.16 \%$ while it decreased $S$ phase and $\mathrm{G}_{2} / \mathrm{M}$ cells from 24.85 and $18.65 \%$ to 21.65 and $12.55 \%$, respectively. The percentages of early and late apoptotic cells were also decreased after APCP treatment. However, APCP treatment did not affect the percentage of normal cells. Xenograft of MDA-MB-231 cells in the APCP treatment group had lower volume and weight than those of control group $(2.70 \pm 1.14 \mathrm{vs}$ $1.41 \pm 0.39 \mathrm{~cm}^{3}$ and $2.7 \pm 0.5$ vs $1.3 \pm 0.2 \mathrm{~g}$ ), accompanied with less vessel formation with a MVD of $5 \pm 1$ compared to the control group's $10 \pm 2$ and an LVD of $4+1$ vs $7+2$. Our results suggest that CD73 may promote tumor growth and serve as a marker of breast cancer progression.
\end{abstract}

Correspondence to: Dr Ping Zhou, Department of Physiology and Pathophysiology, Shanghai Medical College, Fudan University, PO Box 224, 138 Yixueyuan Road, Shanghai 200032, P.R. China E-mail: zping@shmu.edu.cn

Key words: 5'-nucleotidase, breast cancer, cell proliferation, cell cycle, nude mice, angiogenesis

\section{Introduction}

Cell proliferation and metastasis are major characteristics of malignant tumor. Cell proliferation depends on synthesis of a large amount of nucleotide. CD73, also known as ecto-5'nucleotidase, is a membrane-bound glycoprotein (1). Its primary function is to hydrolyze extracellular nucleoside monophosphates into bioactive nucleoside intermediates (2) leading to the generation of extracellular adenosine. The functions of adenosine include vasodilation, stimulation of angiogenesis, cytoprotection, immunosuppression (3) and control of cell growth, maturation and differentiation. Adenosine has been shown as an important metabolite released by cancer cells that elicits physiological responses and promotes tumor progression (4). CD73 has also been described as an adhesion molecule that binds to other cells and extracellular matrix such as laminin and fibronectin $(1,5,6)$. Given that progressive tumor growth depends on vasodilation, angiogenesis, cytoprotective and immunosuppressive activities, CD73 may promote cancer progression. CD73 expression in cancer cell lines is highly variable (5). CD73 expressing cancer cell lines are more invasive in vitro and tumorigenic in nude mice than CD73-negative cell lines (7-14). CD73 activity increased significantly in more aggressive breast cancer, gastric cancer, pancreas cancer and lymphoma (15). Spychala et al found that estradiol significantly downregulates the expression of CD73 through the estrogen receptor (ER). Lack or loss of ER expression is an indicator of more advanced and aggressive breast cancer. Down-regulation of ER selectively increases CD73 expression and extracellular adenosine concentration. Increased generation of adenosine in ER-negative breast cancer has direct tumor-promoting consequences (4).

Although increased adenosine is consistent with faster proliferation of cancer cells (16), a number of studies have shown that activation of adenosine receptors may both stimulate and inhibit cell proliferation $(5,16-23)$. Therefore, the role of CD73 on the growth of cancer cells remains uncertain. In order to further understand the function of CD73 on cancer growth, we investigated the effects of CD73 on human breast cancer cells MDA-MB-231 in culture for proliferation, cell cycle progression, and apoptosis for the first time. The in vivo 
effect of CD73 was examined on MDA-MB-231 tumor xenograft growth in nude mice. We also examined microvessel density (MVD) and lymph vessel density (LVD) of implanted tumor tissues by immunohistochemistry for CD31 and VEGFR-3 staining.

\section{Materials and methods}

Animals and cells. Sixteen 6-week-old male BALB/C-nu/nu mice weighing 19-21 g were purchased from Shanghai Institute for Biological Sciences, Chinese Academy of Sciences, Shanghai, P.R. China. The mice were kept in a laminar-filtered airflow cabinet under pathogen-free conditions with a constant temperature of $25 \pm 3^{\circ} \mathrm{C}$, relative humidity of $40-60 \%$ and $12-\mathrm{h}$ dark/light cycles. Human breast cancer cell line, MDA-MB-231 was purchased from the Institute of Biochemistry and Cell Biology (IBCB) of Chinese Academy of Sciences and cultured in Dulbecco's modified Eagle's medium (DMEM) supplemented with $10 \%$ fetal bovine serum (FBS). DMEM, FBS and trypsin were purchased from Gibco (Langley, OK). $\alpha, \beta-$ methylene adenosine-5'-diphosphate (APCP) and 3-(4,5dimethylthiazol-2-yl)-2,5-diphenyltetrazolium bromide (MTT) were purchased from Sigma-Aldrich (St. Louis, MO). The Annexin V Apoptosis Detection kit was from Calbiochem (San Diego, CA).

Cell viability. Cell viability was determined using the MTT assay according to the manufacturer's instructions (SigmaAldrich). Only live cells reduce the yellow, water-soluble tetrazolium dye to a purple formazan product that is solubilized by DMSO and glycine. The purple color is proportional to the number of cells and the mitochondrial activity. MDAMB-231 cells $\left(5 \times 10^{3}\right)$ in $200 \mu 1$ DMEM were placed into each well of a flat bottom 96-well plate and incubated for $24 \mathrm{~h}$. To evaluate the effect of CD73 on cell viability, the cells were then treated with different concentrations of CD73 inhibitor $\operatorname{APCP}(0,1.5,3,6$ and $12 \mu \mathrm{M})$ for $0,12,24,36$ and $48 \mathrm{~h}$, respectively, prior to the addition of $20 \mu \mathrm{l}$ of MTT solution $(5 \mathrm{mg} / \mathrm{ml}$ in PBS). After being incubated for an additional $4 \mathrm{~h}$ at $37^{\circ} \mathrm{C}$, absorbance at $490 \mathrm{~nm}$ in both treated and untreated cells was measured with a microplate reader to determine cell viability.

Cell cycle. Cell cycle analyses were performed for cells with or without APCP treatment (12 $\mu \mathrm{M}$ APCP for $24 \mathrm{~h}$ ) to determine whether $\mathrm{CD} 73$ regulates the growth phase of breast cancer cells. Cells were prepared by trypsinization followed by centrifugation at $300 \mathrm{x} \mathrm{g}(1000 \mathrm{rpm})$ for $5 \mathrm{~min}$. The cells were resuspended $\left(1 \times 10^{6}\right.$ cells $\left./ \mathrm{ml}\right)$ and fixed with $70 \%$ icecold ethanol for $30 \mathrm{~min}$. The cells were then centrifuged, washed and resuspended in $500 \mu 1$ PBS with $10 \mu 1$ of DNasefree RNase. After 30-min incubation, propidium iodide $(0.05 \mathrm{mg} / \mathrm{ml})$ was added to the solution. The cells were incubated for an additional $15 \mathrm{~min}$ in the dark and filtered through a nylon mesh to remove cell clusters. The fluorescence of propidium iodide of individual cells was measured using FACS Calibur Flow Cytometer (Becton-Dickinson, San Jose, CA). Cell subpopulations in $\mathrm{G}_{0} / \mathrm{G}_{1}, \mathrm{~S}$ and $\mathrm{G}_{2} / \mathrm{M}$ phases were calculated by gating analysis based on differences in DNA content. At least 20000 cells were analyzed per sample. Cell proliferation index $(\mathrm{PIa})$ was calculated as PIa $=\left(\mathrm{S}+\mathrm{G}_{2} / \mathrm{M}\right)$ x $100 \% /\left(\mathrm{G}_{0} / \mathrm{G}_{1}+\mathrm{S}+\mathrm{G}_{2} / \mathrm{M}\right)$.

Cell apoptosis. To determine if CD73 modulates programming death of breast cancer cells, the percentage of apoptotic cells and dead cells are measured by flow cytometry. Apoptotic cells are positive for Annexin V whereas cells that are propidium iodide (PI)-positive are those that have recently died. Briefly, cell staining was performed as follows. Cells were washed twice with cold PBS and resuspended in $300 \mu 1$ Annexin V binding buffer (Becton-Dickinson). To the cell suspension, $5 \mu \mathrm{l}$ fluorescein isothiocyanate-conjugated Annexin $\mathrm{V}$ and $5 \mu 1150 \mu \mathrm{M}$ PI were added. The suspension was then vortexed and incubated at room temperature for $30 \mathrm{~min}$. The samples were washed twice with the binding buffer, and then observed by flow cytometry (Becton-Dickinson). Data analysis was performed by CellQuest software (Becton-Dickinson).

Xenografts in nude mice and treatment. Sixteen mice received subcutaneous injection into the second right mammary fat pad with a $200-\mu 1$ cell suspension containing $2 \times 10^{6}$ MDA-MB231 cells. Subcutaneous tumor node became palpable after a 7 -day transplantation. After 10 days, when established tumors of 5-6 $\mathrm{mm}$ in diameter were detected, drug administration was started. From these 16 mice, 14 mice developed tumors, which were divided into two groups randomly for experiments. $\operatorname{APCP}(50 \mu \mathrm{l})(4 \mathrm{~g} / \mathrm{l}$ in $9 \mathrm{~g} / \mathrm{l}$ saline solution) was injected into the tumor every day in the treatment group and the same volume of $9 \mathrm{~g} / \mathrm{l}$ saline solution was injected in the control group. After 8 days of treatment, $100 \mu 1$ APCP ( $4 \mathrm{~g} / 1$ in $9 \mathrm{~g} / \mathrm{l}$ saline solution) was injected every day for 4 times. The mean tumor volume was measured and calculated according to the formula: $\mathrm{V}=\mathrm{a} \times(\mathrm{b})^{2} \times 0.5$ (a, largest diameter; $\mathrm{b}$, perpendicular diameter). Two weeks after the first APCP treatment, the two groups of mice were sacrificed and the tumors were removed. After the tumors were weighed, they were fixed with formalin and paraffin-embedded $4-\mu \mathrm{m}$ sections were prepared for immunohistochemical analysis.

Immunohistochemical examination and assessment of MVD and LVD. CD31 and VEGFR-3 staining was used to identify the microvessel and lymph vessel density in the tumor tissues by immunohistochemical method. Briefly, after paraffinembedded tissue sections were deparaffinized in xylene and rehydrated in alcohol, sections were incubated in $0.3 \% \mathrm{H}_{2} \mathrm{O}_{2}$ to block endogeneous peroxidase activity. Each slide was incubated with normal goat serum for $20 \mathrm{~min}$ at room temperature, then incubated in the primary antibody, at $4^{\circ} \mathrm{C}$ overnight. After incubation with the secondary antibody, biotinylated for $30 \mathrm{~min}$ at $37^{\circ} \mathrm{C}$, each slide was rinsed in phosphate-buffered saline and was incubated in the avidin-biotin peroxidase complex for $30 \mathrm{~min}$ at $37^{\circ} \mathrm{C}$. The peroxidase was visualized with 3-3'-diamino-benzidinetetrahydrochloride (DAB) solution and then counterstained with hematoxylin.

MVD was assessed according to the international consensus report (24). Immuno-stained slides were scanned at x100 magnification to identify the areas with the highest number of vessels (so called 'hot spot'). Counts were performed on 10 fields in the hot spot by two independent pathologists at x400 magnification and the mean was analyzed. 


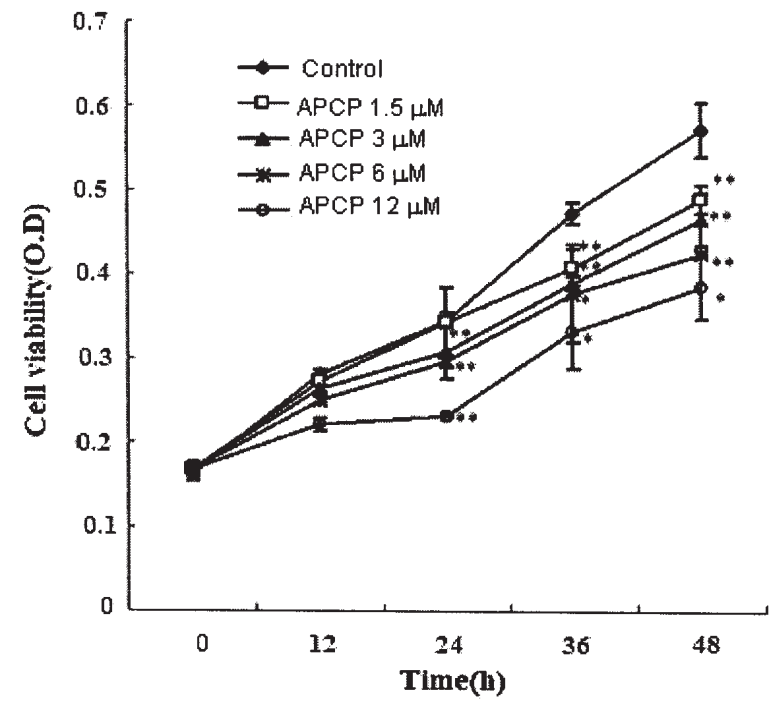

Figure 1. Effect of CD73 inhibitor on cell viability of the MDA-MB-231 cells. Cells were treated with different concentrations of CD73 specific inhibitor (APCP). Cell viability at $0,12,24,36$ and $48 \mathrm{~h}$ was detected using MTT degradation assay, $\mathrm{n}=3 .{ }^{*} \mathrm{P}<0.05,{ }^{* *} \mathrm{P}<0.01$ vs control at the same time-points.

Statistical analysis. All data was expressed as mean \pm standard error and analyzed using one-way ANOVA analysis. A P $<0.05$ was considered statistically significant.

\section{Results}

CD73 inhibitor decreased the viability of MDA-MB-231 cells. APCP is a specific inhibitor of CD73. To examine the effect of CD73 on cell viability, viability time curve of $M D A-M B-231$ cells treated by different concentrations of $\operatorname{APCP}(0,1.5,3,6$ or $12 \mu \mathrm{M})$ was measured by MTT assay. The result showed that APCP inhibited cell viability significantly with a dosedependent manner when compared to untreated control (Fig. 1).

Effect of CD73 inhibitor on cell cycle of MDA-MB-231 cells. To determine the effects of CD73 on cell cycle, DNA content in individual cells was measured by flow cytometry after being stained with fluorescent dye. APCP treatment $(12 \mu \mathrm{M})$
A
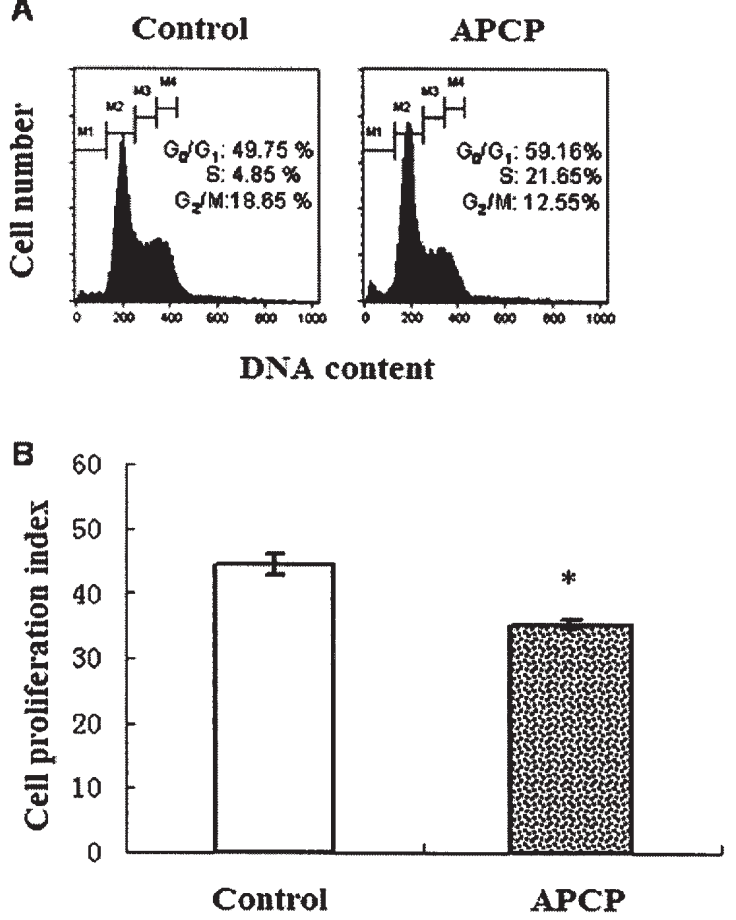

Figure 2. Effect of CD73 inhibitor on the cell cycle of the MDA-MB-231 cells. Cells were incubated with $12 \mu \mathrm{M}$ APCP for $24 \mathrm{~h}$, and then fixed and stained with PI as described in Materials and methods. The stained cells were analyzed by a flow cytometer. (A) Images from one representative experiment. $M 1$, sub- $\mathrm{G}_{1}$ phase; $\mathrm{M} 2, \mathrm{G}_{0} / \mathrm{G}_{1}$ phase; $\mathrm{M} 3, \mathrm{~S}$ phase; $\mathrm{M} 4, \mathrm{G}_{2} / \mathrm{M}$ phase. Percentage data were calculated from three independent experiments. (B) Cell proliferation index (PIa) of control and APCP treated cells. PIa = $\left(\mathrm{S}+\mathrm{G}_{2} / \mathrm{M}\right) \times 100 \% /\left(\mathrm{G}_{0} / \mathrm{G}_{1}+\mathrm{S}+\mathrm{G}_{2} / \mathrm{M}\right) .{ }^{*} \mathrm{P}<0.01$ vs control.

significantly increased $\mathrm{G}_{0} / \mathrm{G}_{1}$ phase cells from 49.75 to $59.16 \%$, and decreased $\mathrm{S}$ and $\mathrm{G}_{2} / \mathrm{M}$ phase cells from 24.85 and $18.65 \%$ to 21.65 and $12.55 \%$, respectively $(\mathrm{P}<0.05$, Fig. $2 \mathrm{~A})$. The proliferation index of APCP-treated cells decreased significantly when compared to untreated control $(\mathrm{P}<0.01$, Fig. 2B).

Effect of CD73 inhibitor on apoptosis of MDA-MB-231 cells. Apoptosis was detected by double labeling method of Annexin
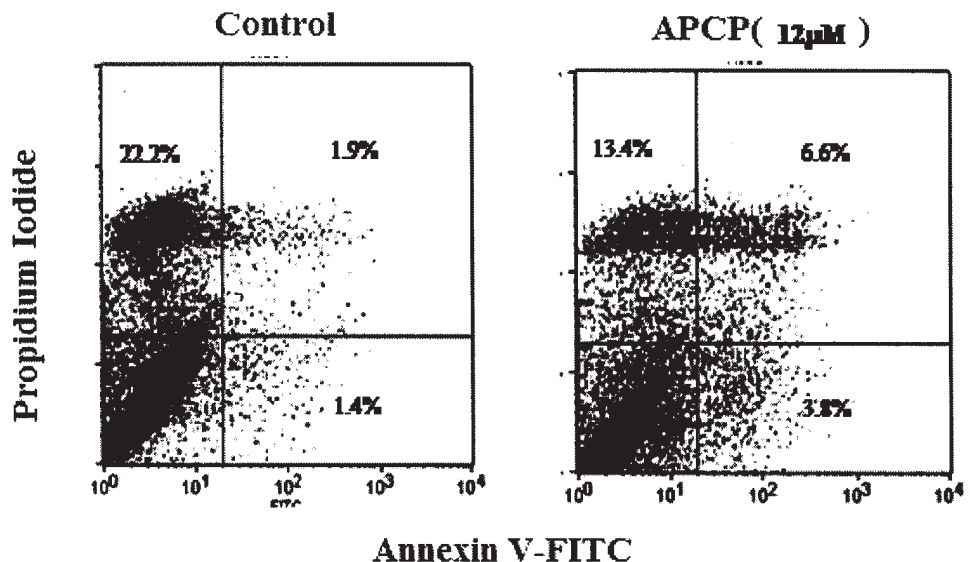

Figure 3. Effect of CD73 inhibitor on apoptosis of the MDA-MB-231 cells. Annexin V-PI staining was performed after the cells were exposed to $12 \mu \mathrm{M}$ APCP for $24 \mathrm{~h}$. The scatter plot of flow cytometry represented gated cells in different liability. Upper left, Annexin $\mathrm{V}^{-} / \mathrm{PI}^{+}$, completely dead cells; upper right, Annexin ${ }^{+} / \mathrm{PI}^{+}$, late apoptotic cells; lower right, Annexin $\mathrm{V}^{+} / \mathrm{PI}^{-}$, viable apoptotic cells; lower left, Annexin $\mathrm{V}^{-} / \mathrm{PI}^{-}$, normal cells. 
$A$

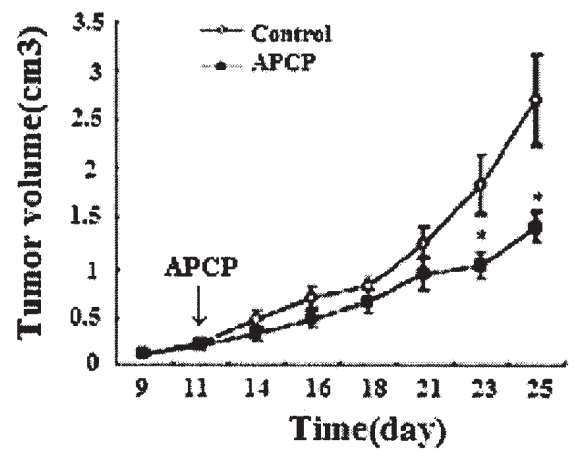

B

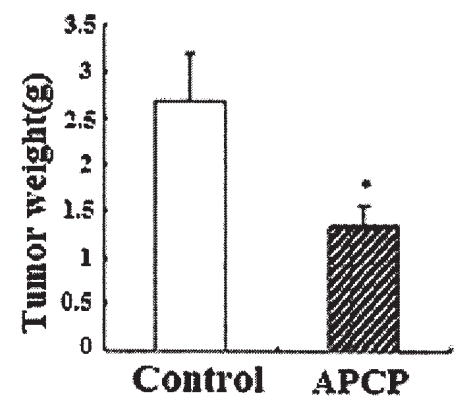

Figure 4. Effect of CD73 inhibitor on transplantation tumor volume and gravimetric of athymic nude mice bearing subcutaneously transplanted MDA-MB-231 human breast cancer cell line. (A) Effect of CD73 inhibitor on transplantation tumor volume. (B) Effect of CD73 inhibitor on transplantation tumor weight. Bars represent standard error (SE). $\mathrm{n}=7,{ }^{*} \mathrm{P}<0.05$, versus control.

A

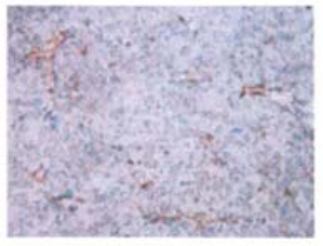

Control

B

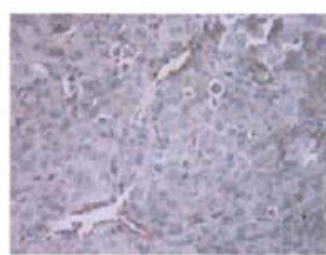

Control

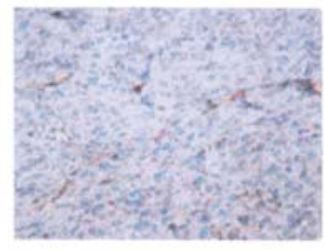

APCP $(x 400)$
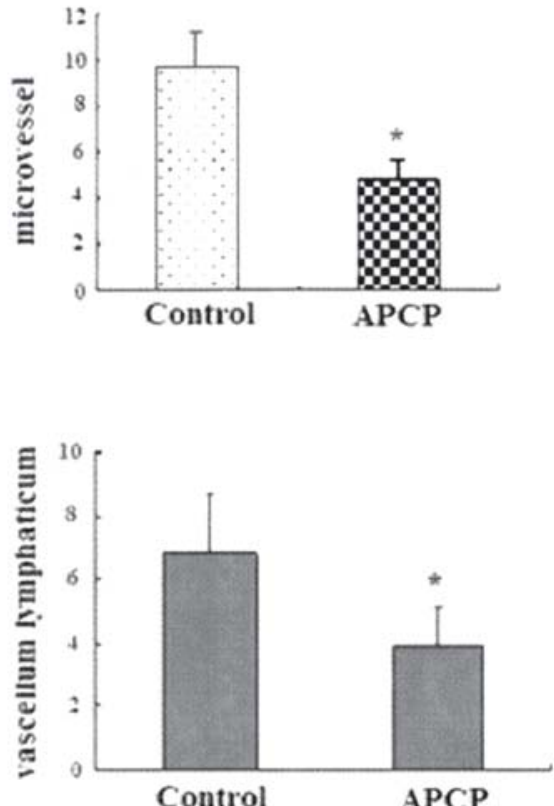

Figure 5. Effect of CD73 inhibitor on MVD and LVD in transplantation tumor. (A) CD31 staining. Athymic nude mice bearing subcutaneously transplanted MDA-MB-231 human breast cancer cell line had less tumor microvessel formation during treatment with the CD73 inhibitor APCP. Bars represent standard error (SE). (B) VEGFR-3 staining. Athymic nude mice bearing subcutaneously transplanted MDA-MB-231 human breast cancer cell line had less tumor lymph vessel formation during treatment with the CD73 inhibitor APCP. Bars represent standard error (SE). $\mathrm{n}=10$, ${ }^{*} \mathrm{P}<0.01 \mathrm{compared}$ with control group.

V-FITC and PI. After 24-h treatment with $12 \mu \mathrm{mol} / 1 \mathrm{APCP}$, both early- (Annexin V-FITC positive only) and late-stage (both Annexin V-FITC and PI positive) apoptotic MDAMB-231 cells increased significantly $(\mathrm{P}<0.05)$. However, the percentage of dead cells in the untreated group was significantly $(\mathrm{P}<0.05)$ higher than in the APCP-treated group. There was no significant difference in percentages of viable cells between the two groups (Fig. 3, P>0.05).

Effect of CD73 inhibitor on breast cancer xenograft growth. Xenograft model was employed to compare $M D A-M B-231$ cell growth with and without APCP treatment. Finally, tumor grafts were collected and weighed two weeks after the first APCP treatment, and tumor tissues with APCP treatment showed significantly decreased volume and weight compared to those of the control group $\left(2.70 \pm 1.14\right.$ vs $1.40 \pm 0.39 \mathrm{~cm}^{3}$ and $2.7 \pm 0.5 \mathrm{~g}$ vs $1.3 \mathrm{~g} \pm 0.2 \mathrm{~g}$; Fig. 4 ).

Influence of CD73 inhibitor on the tumor histology. To further elucidate whether reduced angiogenesis accounts for the suppressed in vivo growth of $M D A-M B-231$ cells, MVD was assessed by immunohistochemistry. As shown in Fig. 5, microvessels were easily observed by CD31 staining. Statistics analysis showed a significantly less MVD was present in the APCP $(100 \mathrm{mg} / \mathrm{kg})$ treatment group $(5 \pm 1)$ compared to $10 \pm 2$ in the control group $(\mathrm{P}<0.01)$. We measured the LVD in tumor tissues by labeled VEGFR-3, which marked lymph vessel density. Statistics analysis showed a significantly less LVD 
was present in the APCP treatment group $(4 \pm 2)$ compared to $7 \pm 2$ in the control group $(\mathrm{P}<0.01)$.

\section{Discussion}

CD73 from tumors such as neurospongioma (25), colon adenocarcinoma (26) and breast cancer (2) has higher activity than normal cells. We previously compared CD73 activity using high-pressure liquid chromatography and mRNA level by RT-PCR of different human breast cancer cell lines. The result showed that CD73 activity and mRNA level on MDA-MB-231, BT549 and MDA435 was higher than MCF-7 and T-47D (27). CD73 activity and metastatic potential is proportionally related (28). The mRNA transcriptional level of MDA-MB-231 human breast cancer cells was highest among the five human breast cancer cell lines tested. Therefore, the MDA-MB-231 cell line was selected to investigate the effect of CD73 on the viability, division and life cycle of human breast cancer cells.

Our study in vitro demonstrated that exposure of MDAMB-231 cells to APCP, a specific CD73 inhibitor, resulted in a dose-dependent decrease in cell viability between the concentrations of 3 and $12 \mu \mathrm{M}$, which is consistent with previous study using glioma cells. In the same study, Wind et al found that besides the importance of the direct effects on cell proliferation and differentiation, CD73 overexpression enhances extracellular adenosine levels, which is an important proliferation stimulator (29). Adenosine stimulates bone marrow cell proliferation. Because the decreased cell viability caused by CD73 inhibition can be the result of either decreased cell proliferation or increased cell death, we observed the effects of APCP on cell cycle, apoptosis and death to clarify the mechanism.

Cell cycle analysis of B16-F10 melanoma cells treated with the A3 adenosine receptor agonist showed a significantly increased percentage of cells in the $\mathrm{G}_{0} / \mathrm{G}_{1}$ phase and decrease in the $\mathrm{S}$ and $\mathrm{G}_{2}$ phases (30). Mujoomdar et al demonstrated that adenosine stimulates breast carcinoma cell proliferation, cell cycling and DNA synthesis by using MTT assay, flow cytometry and $\mathrm{H}^{3}$-Tdr isotopic labeling (31). Because CD73 is one of the speed-limiting enzymes controlling the process of adenosine synthesis, we proposed that CD73 may have similar functions in regulating cell proliferation. In order to prove our hypothesis, cell cycling of MDA-MB-231 breast cancer cells was observed by flow cytometry after APCP treatment. The ratio of $G_{0} / G_{1}$ phase cells to $S$ and $G_{2} / M$ phase cells increased after exposure to APCP for $24 \mathrm{~h}$. The result indicated that APCP may inhibit the progression of breast cancer cells by decreasing $S$ and $G_{2} / M$ phase cells and arresting cells in the $\mathrm{G}_{0} / \mathrm{G}_{1}$ phase of the cell cycle.

Further study was performed to determine the effect of CD73 inhibitor on cell death and apoptosis. Adenosine-induced apoptosis was reported in a number of studies (32-34). Adenosine triggers caspase-independent apoptosis of mouse thymoma cells through a non-classical receptor on the cell surface. However, the effects of CD73 on cell apoptosis and cell death have not been documented. Our data shows that when CD73 activity was inhibited, the percentages of early and late apoptotic cells increased significantly. Interestingly, the percentages of normal cells between the untreated and APCP-treated groups had no difference. The untreated group had more completely dead cells than the APCP-treated group. The result indicated that CD73 inhibition did not induce cell death.

Tumorigenicity assay showed that tumor xenografts of the APCP treatment group grew slower as their volume and weight were smaller than those from the control group. The development of a growing tumor requires an abundant blood supply. Angiogenesis is an important factor in the progression and enlargement of solid neoplasms and has a close relation to invasion and metastases (35). MVD assessment showed significantly decreased angiogenesis in tumors of the APCP treatment group, indicating that an inadequate blood supply might account for suppressed in vivo growth. To our best knowledge, this is the first direct evidence for the role of CD73 in breast cancer angiogenesis. The spread of tumor cells via the lymphatic system is one of the major causes of tumor metastasis. Because VEGFR-3 has been demonstrated to be expressed predominantly in the lymphatic endothelium, we measured LVD in tumor tissues by labeled VEGFR-3. Our results showed that decrease of the LVD in tumor tissue was related to treatment of APCP, suggesting that CD73 plays a crucial role in angiogenesis and lymphangiogenesis, and is closely related to invasion and metastases of tumors.

In summary, CD73 may accelerate the growth of breast cancer in vitro and in vivo by stimulating cell proliferation and tumor angiogenesis. Our results suggest that CD73 may serve as a marker of breast cancer progression.

\section{Acknowledgements}

This study was supported by a grant (no. 30470689) from the National Natural Science Foundation of P.R. China. We thank Tan Zhuo and Bian Wei (FACS Laboratory, Shanghai Biochemistry and Cell Biology Analyses Center, Chinese Academy of Science) for expert technical assistance in flow cytometry analyses.

\section{References}

1. Zimmermann H: 5'-Nucleotidase: molecular structure and functional aspects. Biochem J 285: 345-365, 1992.

2. Canbolat O, Durak I, Cetin R, Kavutcu M, Demirci S and Ozturk S: Activities of adenosine deaminase, 5'-nucleotidase, guanase and cytidine deaminase enzymes in cancerous and noncancerous human breast tissues. Breast Cancer Res Treat 37: 189-193, 1996.

3. Spychala J: Tumor-promoting functions of adenosine. Pharmacol Ther 87: 161-173, 2000.

4. Spychala J, Lazarowski E, Ostapkowicz A, Ayscue LH, Jin A and Mitchell BS: Role of estrogen receptor in the regulation of ecto-5'-nucleotidase and adenosine in breast cancer. Clin Cancer Res 10: 708-717, 2004.

5. Airas L, Niemela J, Salmi M, Puurunen T, Smith DJ and Jalkanen S: Differential regulation and function of CD73, a glycosyl-phosphatidylinositol-linked 70-kD adhesion molecule, on lymphocytes and endothelial cells. J Cell Biol 136: 421-431, 1997.

6. Moriwaki Y, Yamamoto T and Higashino K: Enzymes involved in purine metabolism - a review of histochemical localization and functional implications. Histol Histopathol 14: 1321-1340, 1999.

7. Bagheri-Yarmand R, Mandal M, Taludker AH, Wang RA, Vadlamudi RK, Kung HJ and Kumar R: Etk/Bmx tyrosine kinase activates Pak1 and regulates tumorigenicity of breast cancer cells. J Biol Chem 276: 29403-29409, 2001.

8. Sommers CL, Byers SW, Thompson EW, Torri JA and Gelmann EP: Differentiation state and invasiveness of human breast cancer cell lines. Breast Cancer Res Treat 31: 325-335, 1994. 
9. Gilles C, Bassuk JA, Pulyaeva H, Sage EH, Foidart JM and Thompson EW: SPARC/osteonectin induces matrix metalloproteinase 2 activation in human breast cancer cell lines. Cancer Res 58: 5529-5536, 1998.

10. Manni A, Washington S, Griffith JW, Verderame MF, Mauger D, Demers LM, Samant RS and Welch DR: Influence of polyamines on in vitro and in vivo features of aggressive and metastatic behavior by human breast cancer cells. Clin Exp Metastasis 19: 95-105, 2002.

11. Bachmeier BE, Nerlich AG, Lichtinghagen $R$ and Sommerhoff CP: Matrix metalloproteinases (MMPs) in breast cancer cell lines of different tumorigenicity. Anticancer Res 21: 3821-3828, 2001.

12. Mullen P, Ritchie A, Langdon SP and Miller WR: Effect of Matrigel on the tumorigenicity of human breast and ovarian carcinoma cell lines. Int J Cancer 67: 816-820, 1996.

13. Clarke R: Human breast cancer cell line xenografts as models of breast cancer. The immunobiologies of recipient mice and the characteristics of several tumorigenic cell lines. Breast Cancer Res Treat 39: 69-86, 1996.

14. Rose DP and Connolly JM: Dietary fat and breast cancer metastasis by human tumor xenografts. Breast Cancer Res Treat 46: 225-237, 1997.

15. Linden J: Molecular approach to adenosine receptors: receptormediated mechanisms of tissue protection. Annu Rev Pharmacol Toxicol 41: 775-787, 2001.

16. Mujoomdar M, Hoskin D and Blay J: Adenosine stimulation of the proliferation of colorectal carcinoma cell lines. Roles of cell density and adenosine metabolism. Biochem Pharmacol 66: 1737-1747, 2003.

17. Grant MB, Tarnuzzer RW, Caballero S, Ozeck MJ, Davis MI, Spoerri PE, Feoktistov I, Biaggioni I, Shryock JC and Belardinelli L: Adenosine receptor activation induces vascular endothelial growth factor in human retinal endothelial cells. Circ Res 85: 699-706, 1999.

18. Schulte G and Fredholm BB: Signaling pathway from the human adenosine $\mathrm{A}(3)$ receptor expressed in Chinese hamster ovary cells to the extracellular signal-regulated kinase $1 / 2$. Mol Pharmacol 62: 1137-1146, 2002.

19. Kruger KH, Thompson LF, Kaufmann M and Moller P: Expression of ecto-5'-nucleotidase (CD73) in normal mammary gland and in breast carcinoma. Br J Cancer 63: 114-118, 1991.

20. Fishman P, Madi L, Bar-Yehuda S, Barer F, Del Valle L and Khalili K: Evidence for involvement of Wnt signaling pathway in IB-MECA mediated suppression of melanoma cells. Oncogene 21: 4060-4064, 2002.

21. Meininger CJ and Granger HJ: Mechanisms leading to adenosinestimulated proliferation of microvascular endothelial cells. Am J Physiol 258: H198-H206, 1990.

22. Dubey RK, Gillespie DG and Jackson EK: A (2B) adenosine receptors stimulate growth of porcine and rat arterial endothelial cells. Hypertension 39: 530-535, 2002.
23. Feoktistov I, Garland EM, Goldstein AE, Zeng D, Belardinelli L, Wells JN and Biaggioni I: Inhibition of human mast cell activation with the novel selective adenosine $\mathrm{A}(2 \mathrm{~B})$ receptor antagonist 3-isobutyl-8-pyrrolidinoxanthine (IPDX)(2). Biochem Pharmacol 62: 1163-1173, 2001.

24. Vermeulen PB, Gasparini G, Fox SB, Toi M, Martin L, McCulloch P, Pezzella F, Viale G, Weidner N, Harris AL and Dirix LY: Quantification of angiogenesis in solid human tumours: an international consensus on the methodology and criteria of evaluation. Eur J Cancer 32A: 2474-2484, 1996.

25. Turnay J, Olmo N, Navarro JM, Gavilanes JG and Lizarbe MA: Isolation and characterization of the ecto-5'-nucleotidase from a rat glioblastoma cell line. Mol Cell Biochem 117: 23-33, 1992.

26. Navarro JM, Olmo N, Turnay J, Lopez-Conejo MT and Lizarbe MA: Ecto-5'-nucleotidase from a human colon adenocarcinoma cell line. Correlation between enzyme activity and levels in intact cells. Mol Cell Biochem 187: 121-131, 1998.

27. Zhou TT and Zhou P: Crucial role for ecto-5'-nucleotidase (CD73) in invasion and migration of human breast cancer cell lines. Chin J Pathophysiol 22: 360-364, 2006.

28. Wink MR, Tamajusuku AS, Braganhol E, Casali EA, BarretoChaves ML, Sarkis JJ and Battastini M: Thyroid hormone upregulates ecto-5'-nucleotidase/CD73 in C6 rat glioma cells. Mol Cell Endocrinol 205: 107-114, 2003.

29. Walia M, Mahajan M and Singh K: Serum adenosine deaminase, 5'-nucleotidase and alkaline phosphatase in breast cancer patients. Indian J Med Res 101: 247-249, 1995.

30. Fishman P, Bar-Yehuda S, Barer F, Madi L, Multani AS and Pathak S: The A3 adenosine receptor as a new target for cancer therapy and chemoprotection. Exp Cell Res 269: 230-236, 2001

31. Mujoomdar M, Bennett A, Hoskin D and Blay J: Adenosine stimulation of proliferation of breast carcinoma cell lines: evaluation of the $\left[{ }^{3} \mathrm{H}\right]$ thymidine assay system and modulatory effects of the cellular microenvironment in vitro. J Cell Physiol 201: 429-438, 2004.

32. Kulkarni JS, Przywara DA, Wakade TD and Wakade AR: Adenosine induces apoptosis by inhibiting mRNA and protein synthesis in chick embryonic sympathetic neurons. Neurosci Lett 248: 187-190, 1998.

33. Saitoh M, Nagai K, Nakagawa K, Yamamura T, Yamamoto S and Nishizaki T: Adenosine induces apoptosis in the human gastric cancer cells via an intrinsic pathway relevant to activation of AMP-activated protein kinase. Biochem Pharmacol 67: 2005-2011, 2004.

34. El-Darahali A, Fawcett H, Mader JS, Conrad DM and Hoskin DW: Adenosine-induced apoptosis in EL-4 thymoma cells is caspaseindependent and mediated through a non-classical adenosine receptor. Exp Mol Pathol 179: 249-258, 2005.

35. Vermeulen PB, Gasparini G, Fox SB, Toi M, Martin L, McCulloch P, Pezzella F, Viale G, Weidner N, Harris AL and Dirix LY: Quantification of angiogenesis in solid human tumours: an international consensus on the methodology and criteria of evaluation. Eur J Cancer 32A: 2474-2484, 1996. 